\title{
Grey matter changes in medication-overuse headache before and after medication withdrawal
}

\author{
F Riederer ${ }^{1 *}$, AR Gantenbein ${ }^{1}$, M Marti ${ }^{1}$, R Luechinger ${ }^{2}$, S Kollias ${ }^{3}$, PS Sándor ${ }^{4}$ \\ From The European Headache and Migraine Trust International Congress \\ London, UK. 20-23 September 2012
}

\section{Background}

Medication-overuse headache $(\mathrm{MOH})$ is a complication of migraine that causes significant burden and cost. Recent studies demonstrated metabolic and structural abnormalities in $\mathrm{MOH} 1,2$, including a grey matter increase in the midbrain periaqueductal grey. We hypothesised that structural changes related to $\mathrm{MOH}$ should return to normal after medication withdrawal in patients with significant clinical improvement (responders). In contrast, no changes were expected in patients without improvement (nonresponders).

\section{Methods}

Thirty-one $\mathrm{MOH}$ patients and 28 healthy controls were investigated in a longitudinal voxel-based morphometry study, comparing structural MRIs at 2 time points.

\section{Results}

In responders, grey matter in the midbrain decreased close to normal values after withdrawal. In contrast, in nonresponders no grey matter decrease from scan 1 to scan 2 was observed. At baseline, non-responders had significantly less grey matter in the right and left orbito-frontal cortex, left insula, midbrain, and the thalami compared to responders. In $\mathrm{MOH}$ patients grey matter in the right gyrus rectus at base line correlated positively with treatment response.

\section{Conclusions}

Increased grey matter in the midbrain, which is involved in pain modulation, seems to decrease after successful treatment. Poor response to treatment is associated with

${ }^{1}$ University Hospital Zurich, Department of Neurology, Switzerland Full list of author information is available at the end of the article decreased grey matter in the orbitofrontal cortex, consistent with dysfunction of this region.

\section{Author details}

'University Hospital Zurich, Department of Neurology, Switzerland. ${ }^{2}$ Institute for Biomedical Engineering, Swiss Federal Institute of Technology and the University of Zurich, Switzerland. ${ }^{3}$ Institute of Neuroradiology, University Hospital Zurich, Switzerland. ${ }^{4}$ RehaClinic Bad Zurzach/Baden, Switzerland.

Published: 21 February 2013

\section{References}

1. Fumal A, Laureys S, Di Clemente, et al: Orbitofrontal cortex involvement in chronic analgesic-overuse headache evolving from episodic migraine. Brain 2006, 129(Pt 2):543-550

2. Riederer F, Marti M, Luechinger R, et al: Grey matter changes associated with medication-overuse headache- correlations with disease related disability and anxiety. The World Journal of Biological Psychiatry .

doi:10.1186/1129-2377-14-S1-P177

Cite this article as: Riederer et al:: Grey matter changes in medicationoveruse headache before and after medication withdrawal. The Journal of Headache and Pain 2013 14(Suppl 1):P177.

Submit your manuscript to a SpringerOpen ${ }^{\circ}$ journal and benefit from:

- Convenient online submission

- Rigorous peer review

- Immediate publication on acceptance

- Open access: articles freely available online

- High visibility within the field

Retaining the copyright to your article

Submit your next manuscript at $\boldsymbol{~ s p r i n g e r o p e n . c o m ~}$
(C) 2013 Riederer et al; licensee Springer. This is an Open Access article distributed under the terms of the Creative Commons Attribution License (http://creativecommons.org/licenses/by/2.0), which permits unrestricted use, distribution, and reproduction in any medium, provided the original work is properly cited. 